\title{
Work Accident Analysis in the Construction Project of PT. XYZ
}

\author{
Rosalendro Eddy Nugroho, Angga Sunbara
}

\begin{abstract}
This thesis analyzes work accidents in a construction project at PT XYZ in order to reduce the impact or risk of work accidents during future project implementation. This study uses a risk management that combines two tools, namely the failure mode and effect analysis method and the fishbone diagram. The FMEA method is used to identify all activities that are at risk of causing accidents and to analyze the level of severity, while the fishbone diagram method is used to analyze the causes of accidents. After calculating, the results of the highest RPN value were exposed to sharp objects when installing iron and formwork at 60 , fall from a height when concrete casting by 30 , pinched during material mobilization of the concrete material by 30 , accidents caused by working tools during iron and formwork amounted to 18 , fall from the same height while working iron construction by 18 , fire caused by welding at the time of installing the water pipe by 16 , tripping / slipping at the work location during the installation of iron and formwork by 15. Based on the analysis, work accidents often occur during structural work. The improvements made were the method factor, namely the improvement in the method of implementing project security support elements, making a one gate system as an access in and out of workers for screening worker PPE and providing emergency response training. Environmental factors, namely renewal of the SOP by checking the conditions of the work environment before the work is carried out by $\mathrm{K3}$ officers and site operational managers (SOM). Material factors, namely providing protection for material storage, checking the quality of the main raw materials carried out by quality control officers and cleaning used materials that are still attached after casting. The machine factor is checking the operational permit for each tool before the equipment arrives, doing preventive maintenance on every tool used in the project and updating the tools with a safer work system. Man factors are changes in the project operational management structure, the application of punishment for workers who violate the OHS rules, and the implementation of workforce training accompanied by the National Professional Certification Agency (BNSP).
\end{abstract}

Index Terms - FMEA, fishbone diagram, work accidents, risk priority number.

\section{INTRODUCTION}

\section{A. Backgroundof Problems}

The construction sector is an important part of the development of a country, where construction projects for the construction of buildings, roads, bridges and other infrastructure are a measure of the country's economic development. The success of construction projects is traditionally measured in terms of time, cost and quality; This

Rosalendro Eddy Nugroho, senior lecturer in Master Program in Post-Graduate Management from Universitas Mercu Buana Jakarta

Angga Sunbara, Postgraduate Management Masters Program at the University of Mercu Buana Jakarta success is influenced by important factors (Critical Success Factors, CFS). One of these CFSs is the safety aspect in project implementation. Work accidents on construction projects can cause work to stop, lower morale, resulting in decreased productivity(Benny Hidayat \& Anggraini, 2016).

PT XYZ Established since 1953 is one of the state-owned companies engaged in the construction sector, where this company has various kinds of development projects spread across several regions of Indonesia. PT XYZ also works in other related business fields, such as building management, property and realty development.

This company has implemented a work safety and occupational health system in order to achieve its Zero Accident commitment. Therefore, risk management in the company must be considered in order to reduce and prevent things that have the potential to cause work accidents in the project.

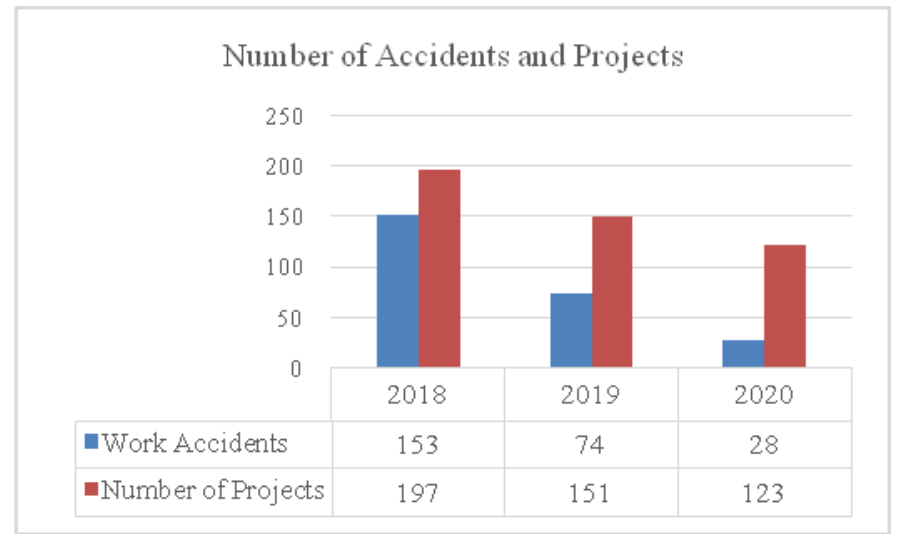

Fig 1:-Number of Accidents and Projects Source : PT XYZ (2018 - 2020)

From the data above, it can be seen that work accidents at PT XYZ from 2018-2020 still occur frequently. Based on Figure 1 , data on the number of projects and the number of work accidents, the more projects that are carried out, the higher the risk of work accidents that occur.

From these data, it is necessary to have a deeper analyzer to solve the problems faced by PT XYZ. Analysis can be carried out on work accidents by using a risk assessment between the severity, frequency and detection of work accidents to determine priorities and factors causing work accidents through the Failure Mode and Effect Analysis method and the Fisbone Diagram Method.With this research, it is hoped that it can help PT XYZ achieve its goals in achieving the desired targets. Based on the results of the description above, the writer is interested in taking the title "Work Accident Analysis in the Construction Project of PT. XYZ".

\section{B. Research Purposes}

There are several purpose which to be want to reach in 
carrying out this research such as:

1) Knowing the level of risk of work accidents at the time of construction project implementation.

2) Knowing the causes of work accidents that occur during construction projects.

3) Provide suggestions for improvements to be made to reduce the rate of work accidents in construction projects.

\section{THEORITICAL REVIEW}

A. Occupational Health and Safety Management System According to PP No. 50 of 2012 Occupational health and safety management systems or often called SMK3 are part of the overall management system which includes organizational structure, planning, responsibilities, implementation, procedures, processes and resources needed for development, implementation, and achievement. , assessing and maintaining OHS policies in the context of controlling risks related to work in order to create a safe, efficient and productive workplace (Fitriyaningrum, 2018).

\section{B. Work accident}

According toDauly(2010),occupational safety and health are the main means of preventing accidents, disabilities and deaths due to work accidents.Good work safety is a gateway for workforce security. Work accidents can cause indirect losses, such as damage to work machines and equipment, interruption of the production process for a while, and damage to the work environment.

According to the ILO cited bySebastianus(2015), occupational safety and health is a promotion, protection and improvement of health status which as much as possible includes physical, mental and social aspects for the welfare of workers in the workplace.Occupational safety and health are defined as efforts to carry out a job without causing accidents and to make the work atmosphere free from all kinds of dangers so that high work productivity will be achieved.

\section{Failure Modes and Effect Analysis (FMEA)}

Failure mode and effect analysis (FMEA) is a systematic method and as such is capable of analyzing system risk from the concept phase to system exhaust, detecting failures in the design stage, and determining control measures and corrective actions for failures to reduce their impact.According toKangavari (2015), the purpose of FMEA is to identify risks that have occurred and determine the reduction in the number of priority risks (RPN) after implementation is carried out.

\section{FishboneDiagram}

Fishbone diagram (also called Ishikawa diagram or cause and effect diagram) is a graphic technique for showing some causes of a particular event or phenomenon. In particular, a fishbone diagram (similar in shape to a fish skeleton) is a commonly used tool for cause and effect analysis to identify complex interactions of the causes of a particular problem or event. A fishbone diagram can be a comprehensive theoretical framework for representing and analyzing sources of innovation (Coccia, 2017).

\section{E. Thinking Framework}

Based on discussion of theoretical studies and research phenomena, the writer could summarizes systematically the link between research phenomena as in these following framework: 


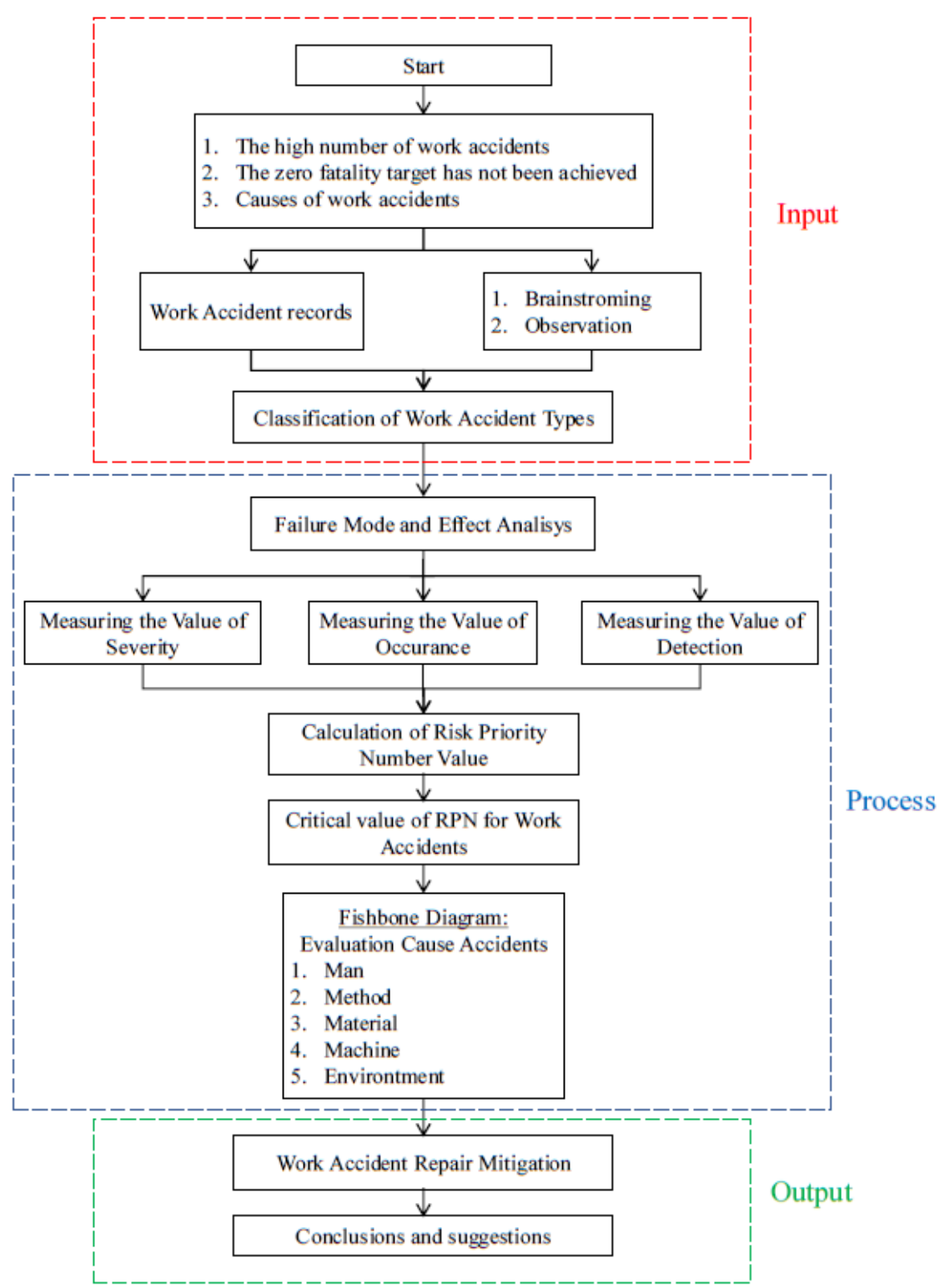

Fig2:-Thinking Framework

high number of work accidents in construction projects.

\section{METHODOLOGY}

In this research, the writer uses descriptive quantitative research, which is research that describes or describes the characteristics of a situation or object of research carried out through data collection and quantitative data analysis. This research is used to test the concept of Failure Mode and Effect Analysis (FMEA) and the concept of Fishbone diagram as a work safety system in examining the factors that cause work accidents in a construction project at PT XYZ. The sample in this study was work accidents during the last three years, namely the period 2018, 2019 and 2020.The sampling technique used is the non-probability technique of purposive sampling, where the sampling method is to select subjects based on specific criteria set by the researcher.The process of implementing a building construction project is one of the project completion processes. The problem that occurs is the
Primary data in this study, the results of observations and brainstorming of researchers while conducting research at PT $\mathrm{XYZ}$. Secondary data used in this study is the work accident report data during the implementation of the building division construction project by departments such as Safety and Operations, which are related to work accidents.

Data analysis methods in this study are 1) Identification of work accidents, 2) Analysis using Failure Mode and Effect Analysis, 3) Analysis using fishbone diagram.

\section{RESULTS AND DISCUSSION}

The data obtained came from the results of observations and interviews. This is done to find out about work accidents that occur within the company environment. From these results, data is obtained which will then be processed using predetermined methods. The following is the identification data of potential work accidents that occur at PT XYZ: 


\section{Work Accident Analysis in the Construction Project of PT. XYZ}

Table 1:-Work Accident Risk Identification

\begin{tabular}{|c|c|c|c|}
\hline No & Type of Work & Variable & Failure Mode \\
\hline \multirow[t]{2}{*}{1} & \multirow[t]{2}{*}{ Excavation work } & \multirow[t]{2}{*}{ Basement Excavation } & Accidents caused by working tools \\
\hline & & & The excavation collapsed \\
\hline \multirow[t]{9}{*}{2} & \multirow[t]{9}{*}{ Structural Work } & \multirow[t]{9}{*}{ Formwork and Iron Installation } & Falling objects or flying particles \\
\hline & & & Expose to a sharp object (iron tip) \\
\hline & & & Accidents caused by working tools (Bar cutter and bar bender) \\
\hline & & & Affected sling at the time of transfer of material \\
\hline & & & Pinched by the sling when binding the material \\
\hline & & & Wedged by iron \\
\hline & & & Tripping or slipping on the jobsite \\
\hline & & & Scaffolding collapsed at the time of installation of iron \\
\hline & & & Fall from the same height while working iron construction \\
\hline \multirow[t]{6}{*}{3} & \multirow[t]{6}{*}{ Structural Work } & \multirow[t]{6}{*}{ Casting concrete } & Fall from a height when casting \\
\hline & & & Accidents caused by working tools (Cast bucket) \\
\hline & & & Expose to a sharp object (formwork tip) \\
\hline & & & Tripping or slipping on the jobsite \\
\hline & & & Pinched during material mobilization \\
\hline & & & Scaffolding collapsed at the time of casting \\
\hline \multirow[t]{3}{*}{4} & \multirow[t]{3}{*}{ Roof Installation } & \multirow[t]{3}{*}{ Frame Roof Installation } & Exposed to sharp objects or roofing material \\
\hline & & & Accidents caused by working tools (drill tools, welding tools) \\
\hline & & & Fall from a height during roof installation \\
\hline \multirow[t]{6}{*}{5} & \multirow[t]{6}{*}{ Architectural Work } & \multirow[t]{6}{*}{ Installation of Walls, Doors, Ceramics and Ceiling } & Expose to a sharp object \\
\hline & & & Hit by brick material \\
\hline & & & Tripping or slipping on the jobsite \\
\hline & & & The scaffolding collapses at the time of installing the ceiling \\
\hline & & & Falling objects or flying particles \\
\hline & & & Fall from the same height \\
\hline \multirow[t]{5}{*}{6} & \multirow{5}{*}{ Fasade work } & \multirow{5}{*}{$\begin{array}{l}\text { Outer Glass Installation and Alumunium } \\
\text { composite panel }\end{array}$} & Fall from the gondola \\
\hline & & & Expose to a sharp object (nail) \\
\hline & & & Exposed to glass material / ACP during material mobilization \\
\hline & & & Falling objects or flying particles \\
\hline & & & Accidents caused by working tools (hammers, cutting tools) \\
\hline \multirow[t]{5}{*}{7} & \multirow{5}{*}{$\begin{array}{l}\text { Mecanical and } \\
\text { Electrical Work }\end{array}$} & \multirow[t]{5}{*}{ Pump and Generator Installation } & Clamped by the pump / generator during mobilization \\
\hline & & & Expose to a sharp object \\
\hline & & & Tripping or slipping on the jobsite \\
\hline & & & Exposure to substances / gases during welding \\
\hline & & & Contact with electricity at the time of installing the pump / generator \\
\hline \multirow[t]{6}{*}{8} & \multirow[t]{6}{*}{ Electrical installation } & Electrical Network Installation & Fall from the same height \\
\hline & & & Expose to a sharp object (cable tray) \\
\hline & & & Exposure to substances / gases during welding \\
\hline & & & Touched with liquids or hot surfaces \\
\hline & & & Contact with electricity \\
\hline & & & Accidents caused by working tools \\
\hline 9 & Installation of water & Iron pipe installation & Fall from the same height \\
\hline & networks & & Expose to a sharp object \\
\hline & & & Clamped in the pipe during installation \\
\hline & & & Exposure to substances / gases during welding \\
\hline & & & Touched with liquids or hot surfaces \\
\hline & & & Fire caused by welding \\
\hline
\end{tabular}

\section{A. Analyzing Accident Risk Variables Using Failure Mode and Effect Analysis Method}

\section{Evaluation of Severity Assessment}

The level of severity is graded starting from level 1 to 5 . A score of 5 indicates the level with the most severe impact while a value of 1 is the level with the least impact. The most severe impact is the loss of life. While the mildest impact is mild irritation and only causes minor injuries. Overall, the severity level used in this study was adopted from the Incident Severity(Apriyan et al, 2017). The following can be seen in the table below:

Table 2:-Severity Scale

\begin{tabular}{|l|l|}
\hline Severity & Level \\
\hline Slight irritation & 1 \\
\hline $\begin{array}{l}\text { Allergies and bruises } \\
\text { Aches, sprains and scratches }\end{array}$ & 2 \\
\hline $\begin{array}{l}\text { Tearing, burns and hyperthermia } \\
\text { Fracture }\end{array}$ & 3 \\
\hline $\begin{array}{l}\text { Severe fracture, severe irritation, surgery and amputation } \\
\text { Hypertemia sufferers lose consciousness }\end{array}$ & 4 \\
\cline { 2 - 3 }
\end{tabular}


Trauma after the incident

Damage to the spine

Fatal events such as death

Source: (Cayman Bussiness System: FMEA, 2002 in Levi, 2017)

\section{Evaluation ofOccurance Assessment}

Occurrence is the frequency of the specific failure causes of a project and results in a failure with a rating of 1 to 5 . To adjust to the existing problems, the occurence table uses simple interpolation, namely by using the most number of accidents occurring and the highest ranking value. The simple way of calculating interpolation is:

Rangking $\mathrm{X}=\frac{y-y 1}{y 2-y 1}=\frac{x-x 1}{x 2-x 1}$

Example calculation:

Ranking $2=\frac{5-1}{2-1}=\frac{71-0}{x-0}=17,75=18$

Thus, the frequency obtained for ranking 2 is $1-18$ cases.

Description::

$y=$ highest score

$y 1=$ lowest score

$y 2=\operatorname{score} x$

$x=$ the highest value

$x 1=$ lowest value

$x 2=$ value $x$

Based on the formula above, the frequency of each ranking on the occurance table is obtained, as follows:

Table 3:- Occurance Scale

\begin{tabular}{|c|l|c|c|}
\hline $\begin{array}{c}\text { Probability } \\
\text { of Failure }\end{array}$ & Criteria & $\begin{array}{c}\text { Freque } \\
\text { ncy }\end{array}$ & $\begin{array}{c}\text { Rank } \\
\text { ing }\end{array}$ \\
\hline Never & $\begin{array}{l}\text { Accidents never } \\
\text { happen }\end{array}$ & 0 & 1 \\
\hline Low & $\begin{array}{l}\text { Accidents occur at } \\
\text { low levels }\end{array}$ & $1-18$ & 2 \\
\hline Medium & $\begin{array}{l}\text { Accidents occur at } \\
\text { a moderate level }\end{array}$ & $19-36$ & 3 \\
\hline High & $\begin{array}{l}\text { Accidents occur at } \\
\text { a high level }\end{array}$ & $37-53$ & 4 \\
\hline $\begin{array}{c}\text { Almost } \\
\text { always }\end{array}$ & $\begin{array}{l}\text { Accidents are } \\
\text { always high }\end{array}$ & $53-71$ & 5 \\
\hline
\end{tabular}

Source: (Cayman Bussiness System: FMEA, 2002 inLevi, 2017)

\section{Evaluation of Detection Assessment}

Detection is a description of how the effectiveness and methods of detection or prevention are failure modes with a rating of 1 to 5 .

Table 4:-Detection Scale

\begin{tabular}{|l|l|c|}
\hline Probability of Failure & Criteria & Ranking \\
\hline Almost certainly & $\begin{array}{c}\text { The ability of the controller to detect and causes almost } \\
\text { certainly }\end{array}$ & 1 \\
\hline High & The controller's ability to detect causes is high & 2 \\
\hline Medium & The ability of the controller to detect moderate causes & 3 \\
\hline Low & The controller's ability to detect causes is low & 4 \\
\hline Not detected & There is no controller capable of detecting & 5 \\
\hline
\end{tabular}

Source: (Cayman Bussiness System: FMEA, 2002 in Levi, 2017) 


\section{Work Accident Analysis in the Construction Project of PT. XYZ}

\section{Calculation of RPN Value (Risk Priority Number)}

The Risk Priority Number is a mathematical product of the severity, level of frequency or possible causes of failure related to the effect and ability to detect failures before they occur. To get the RPN value, it can be shown by the equation below:

\section{RPN = S (Severity) x O (Occurance $)$ x D (Detection $)$}

After calculating the RPN value, the critical RPN value can be calculated. This critical RPN is used as an initial step and countermeasures to reduce work accidents. The critical value of the RPN can be calculated with a formula (Suryani, 2018):

\section{Total RPN $\quad 678,5$}

Critical RPN $=\overline{\text { Total Risk }}=\overline{48}=14,1354$

After calculation can know the critical value RPN is 14.1354. So that the risk of work accidents that exceeds this value is included in the critical risk category.

\begin{tabular}{|c|c|c|c|c|c|c|c|c|}
\hline No & Type of Work & Variable & Failure Mode & $\mathrm{S}$ & $\mathrm{O}$ & $\mathrm{D}$ & RPN & $\begin{array}{c}\text { Critical RPN } \\
(14.13) \\
\end{array}$ \\
\hline \multirow[t]{2}{*}{1} & \multirow[t]{2}{*}{ Excavation work } & \multirow{2}{*}{$\begin{array}{l}\text { Basement } \\
\text { Excavation }\end{array}$} & Accidents caused by working tools & 2 & 1 & 3 & 6 & Not critical \\
\hline & & & The excavation collapsed & 4 & 1 & 1 & 4 & Not critical \\
\hline \multirow[t]{9}{*}{2} & \multirow[t]{9}{*}{ Structural Work } & \multirow{9}{*}{$\begin{array}{l}\text { Formwork and } \\
\text { Iron Installation }\end{array}$} & Falling objects or flying particles & 2 & 3 & 2 & 12 & Not critical \\
\hline & & & Expose to a sharp object (iron tip) & 3 & 5 & 4 & 60 & Critical \\
\hline & & & Accidents caused by working tools (Bar cutter and bar bender) & 3 & 2 & 3 & 18 & Critical \\
\hline & & & Affected sling at the time of transfer of material & 3 & 2 & 2 & 12 & Not critical \\
\hline & & & Pinched by the sling when binding the material & 3 & 2 & 2 & 12 & Not critical \\
\hline & & & Wedged by iron & 2 & 2 & 5 & 20 & Critical \\
\hline & & & Tripping or slipping on the jobsite & 1 & 3 & 5 & 15 & Critical \\
\hline & & & Scaffolding collapsed at the time of installation of iron & 3 & 2 & 1 & 6 & Not critical \\
\hline & & & Fall from the same height while working iron construction & 3 & 2 & 3 & 18 & Critical \\
\hline \multirow[t]{6}{*}{3} & \multirow[t]{6}{*}{ Structural Work } & \multirow[t]{6}{*}{ Casting concrete } & Fall from a height when casting & 5 & 2 & 3 & 30 & Critical \\
\hline & & & Accidents caused by working tools (Cast bucket) & 3 & 1 & 3 & 9 & Not critical \\
\hline & & & Expose to a sharp object (formwork tip) & 2 & 1 & 4 & 8 & Not critical \\
\hline & & & Tripping or slipping on the jobsite & 1 & 2 & 5 & 10 & Not critical \\
\hline & & & Pinched during material mobilization & 3 & 2 & 5 & 30 & Critical \\
\hline & & & Scaffolding collapsed at the time of casting & 2 & 2 & 1 & 4 & Not critical \\
\hline \multirow[t]{3}{*}{4} & \multirow[t]{3}{*}{ Roof Installation } & \multirow{3}{*}{$\begin{array}{l}\text { Frame Roof } \\
\text { Installation }\end{array}$} & Exposed to sharp objects or roofing material & 2 & 2 & 4 & 16 & Critical \\
\hline & & & Accidents caused by working tools (drill tools, welding tools) & 3 & 2 & 3 & 18 & Critical \\
\hline & & & Fall from a height during roof installation & 5 & 1 & 3 & 15 & Not critical \\
\hline \multirow[t]{6}{*}{5} & \multirow{6}{*}{$\begin{array}{l}\text { Architectural } \\
\text { Work }\end{array}$} & \multirow{6}{*}{$\begin{array}{l}\text { Installation of } \\
\text { Walls, Doors, } \\
\text { Ceramics and } \\
\text { Ceiling }\end{array}$} & Expose to a sharp object & 2 & 2 & 4 & 16 & Critical \\
\hline & & & Hit by brick material & 3 & 2 & 2 & 12 & Not critical \\
\hline & & & Tripping or slipping on the jobsite & 1 & 2 & 5 & 10 & Not critical \\
\hline & & & The scaffolding collapses at the time of installing the ceiling & 3 & 2 & 1 & 6 & Not critical \\
\hline & & & Falling objects or flying particles & 2 & 2 & 2 & 8 & Not critical \\
\hline & & & Fall from the same height & 3 & 2 & 3 & 18 & Critical \\
\hline \multirow[t]{5}{*}{6} & \multirow[t]{5}{*}{ Fasade work } & \multirow{5}{*}{$\begin{array}{l}\text { Outer Glass } \\
\text { Installation and } \\
\text { Alumunium } \\
\text { composite panel }\end{array}$} & Fall from the gondola & 5 & 1 & 3 & 15 & Critical \\
\hline & & & Expose to a sharp object (nail) & 3 & 2 & 5 & 30 & Critical \\
\hline & & & Exposed to glass material / ACP during material mobilization & 2 & 1 & 5 & 10 & Not critical \\
\hline & & & Falling objects or flying particles & 2 & 2 & 1 & 4 & Not critical \\
\hline & & & Accidents caused by working tools (hammers, cutting tools) & 3 & 2 & 3 & 18 & Critical \\
\hline \multirow[t]{5}{*}{7} & \multirow{5}{*}{$\begin{array}{l}\text { Mecanical and } \\
\text { Electrical Work }\end{array}$} & & Clamped by the pump / generator during mobilization & 3 & 1 & 5 & 15 & Critical \\
\hline & & Generator & Expose to a sharp object & 2 & 1 & 5 & 10 & Not critical \\
\hline & & & Tripping or slipping on the jobsite & 1 & 1 & 5 & 5 & Not critical \\
\hline & & & Exposure to substances / gases during welding & 3 & 1 & 2 & 6 & Not critical \\
\hline & & & Contact with electricity at the time of installing the pump / generator & 3 & 1 & 1 & 3 & Not critical \\
\hline 8 & Electrical & Electrical Network & Fall from the same height & 3 & 2 & 3 & 18 & Critical \\
\hline & installation & Installation & Expose to a sharp object (cable tray) & 3 & 2.5 & 4 & 30 & Critical \\
\hline & & & Exposure to substances / gases during welding & 3 & 2 & 2 & 12 & Not critical \\
\hline & & & Touched with liquids or hot surfaces & 2 & 1 & 2 & 4 & Not critical \\
\hline & & & Contact with electricity & 3 & 1 & 1 & 3 & Not critical \\
\hline & & & Accidents caused by working tools & 3 & 2 & 3 & 18 & Critical \\
\hline 9 & Installation of & Iron pipe & Fall from the same height & 3 & 2 & 3 & 18 & Critical \\
\hline & water networks & installation & Expose to a sharp object & 3 & 2 & 3 & 18 & Critical \\
\hline & & & Clamped in the pipe during installation & 1 & 2.5 & 5 & 12.5 & Not critical \\
\hline & & & Exposure to substances / gases during welding & 3 & 2 & 2 & 12 & Not critical \\
\hline & & & Touched with liquids or hot surfaces & 2 & 2 & 2 & 8 & Not critical \\
\hline & & & Fire caused by welding & 4 & 2 & 2 & 16 & Critical \\
\hline
\end{tabular}

Based on table 5, it can be concluded that of the 48 failure modes / risks in work accidents at PT XYZ during the last 3 years, 21 of them have an RPN value above 14.13 which is the critical value of RPN. Therefore, further analysis is needed with the Pareto diagram to determine the type of work that will be prioritized, as follows: 


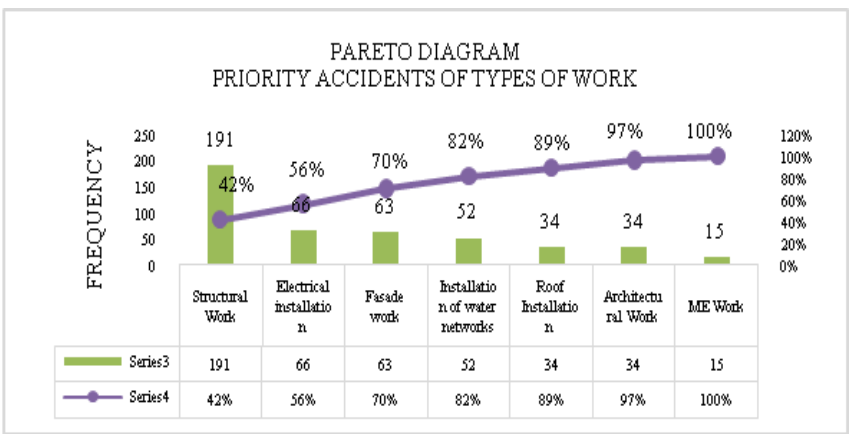

Fig 3:-Accident Priority Pareto Diagram by Type of Work

From Figure 3 it is known that accidents often occur during structural work. The next step is grouping based on the failure mode category. This is done to simplify the identification process, based on the Pareto diagram structural work is a priority. The following is a grouping of sources of occupational accident risk:

Table 6:-Work Accident Priority Grouping

\begin{tabular}{|c|c|c|c|c|}
\hline No & Type of Work & Variable & Failure Mode & RPN \\
\hline \multirow[t]{5}{*}{1} & Structural Work & Formwork and Iron Installation & Expose to a sharp object (iron tip) & 60 \\
\hline & Fasade work & Outer Glass Installation and Alumunium composite panel & Expose to a sharp object (nail) & 30 \\
\hline & Electrical installation & Electrical Network Installation & Expose to a sharp object (cable tray) & 30 \\
\hline & Roof Installation & Frame Roof Installation & Expose to a sharp object or roofing material & 16 \\
\hline & Architectural Work & Installation of Walls, Doors, Ceramics and Ceiling & Expose to a sharp object & 16 \\
\hline \multirow[t]{2}{*}{2} & Structural Work & Casting concrete & Fall from a height when casting & 30 \\
\hline & Fasade work & Outer Glass Installation and Alumunium composite panel & Fall from the gondola & 15 \\
\hline \multirow[t]{3}{*}{3} & Structural Work & Casting concrete & Pinched during material mobilization & 30 \\
\hline & Structural Work & Formwork and Iron Installation & Wedged by iron & 20 \\
\hline & $\begin{array}{l}\text { Mecanical and Electrical } \\
\text { Work }\end{array}$ & Pump and Generator Installation & Clamped by the pump / generator during mobilization & 15 \\
\hline \multirow[t]{5}{*}{4} & Structural Work & Formwork and Iron Installation & Accidents caused by working tools (Bar cutter and bar bender) & 18 \\
\hline & Roof Installation & Frame Roof Installation & Accidents caused by working tools (drill tools, welding tools) & 18 \\
\hline & Fasade work & Outer Glass Installation and Alumunium composite panel & Accidents caused by working tools (hammers, cutting tools) & 18 \\
\hline & Electrical installation & Electrical Network Installation & Accidents caused by working tools & 18 \\
\hline & $\begin{array}{l}\text { Installation of water } \\
\text { networks }\end{array}$ & Iron pipe installation & Accidents caused by working tools & 18 \\
\hline \multirow[t]{4}{*}{5} & Structural Work & Formwork and Iron Installation & Fall from the same height while working iron construction & 18 \\
\hline & Architectural Work & Installation of Walls, Doors, Ceramics and Ceiling & Fall from the same height & 18 \\
\hline & Electrical installation & Electrical Network Installation & Fall from the same height & 18 \\
\hline & $\begin{array}{l}\text { Installation of water } \\
\text { networks }\end{array}$ & Iron pipe installation & Fall from the same height & 18 \\
\hline 6 & $\begin{array}{l}\text { Installation of water } \\
\text { networks }\end{array}$ & Iron pipe installation & Fire caused by welding & 16 \\
\hline 7 & Structural Work & Formwork and Iron Installation & Tripping or slipping on the jobsite & 15 \\
\hline
\end{tabular}

From table 6 it can be seen that the grouping of risk sources obtained from the FMEA analysis process, namely 21 priority failure modes for handling work accidents in the PT XYZ project are divided into seven groups, namely the failure mode group being expose to a sharp object, fall from a height, Pinched during material, accidents cause work tools. , fall from the same height, fire and tripping or slipping on the job site. The next step is that the highest RPN value in each group is analyzed with the help of a fishbone diagram to determine the root cause.

B. Fishbone Diagram Analisys

The process of identifying the causes of work accidents in the PT XYZ construction project was identified using a fishbone diagram. This analysis was carried out by direct observation in the field and conducting interviews and discussions with related employees. Interviews and discussions aim to determine the possible causes of high work accidents in the project. 
Work Accident Analysis in the Construction Project of PT. XYZ

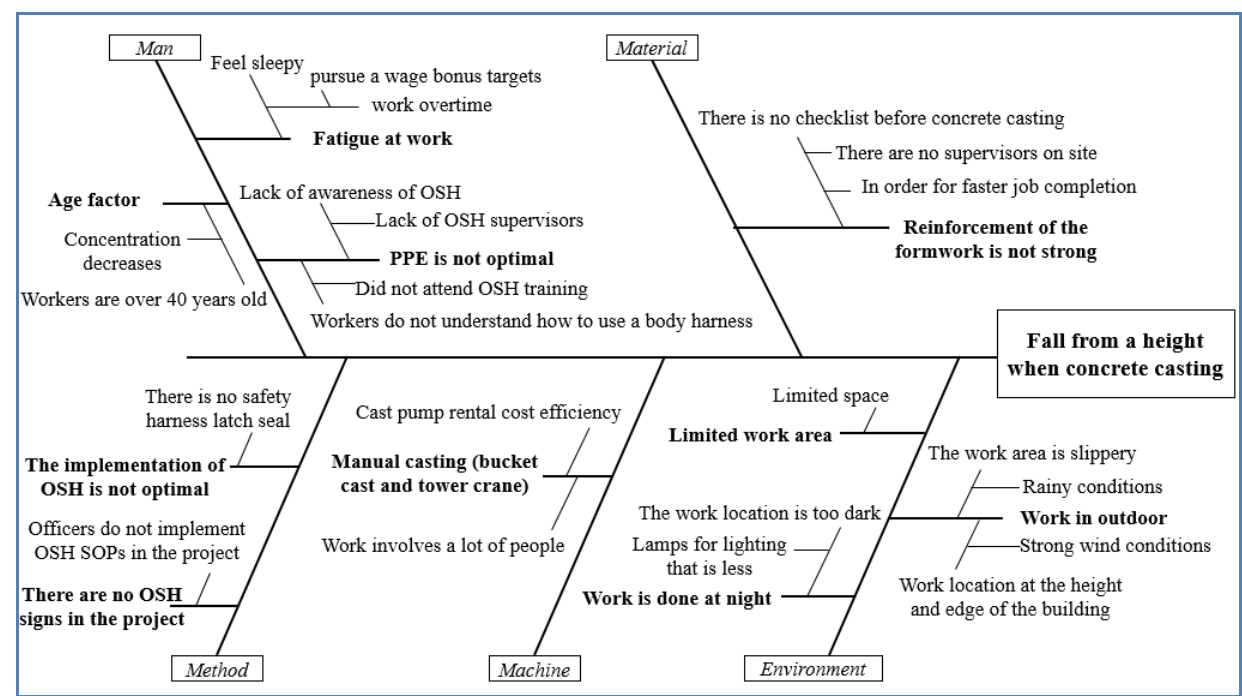

Fig 6:-Fishbone diagram of exposed to sharp objects (iron / formwork)

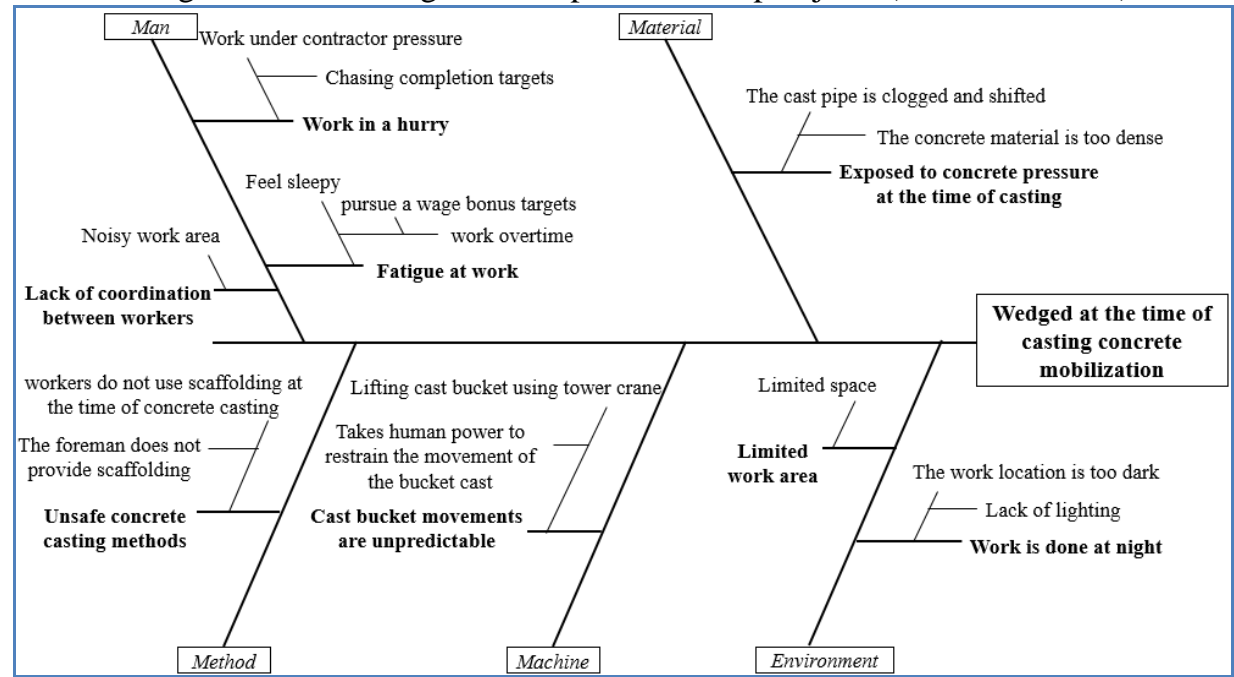

Fig 7:-Fishbone diagram offalling from height when casting concrete

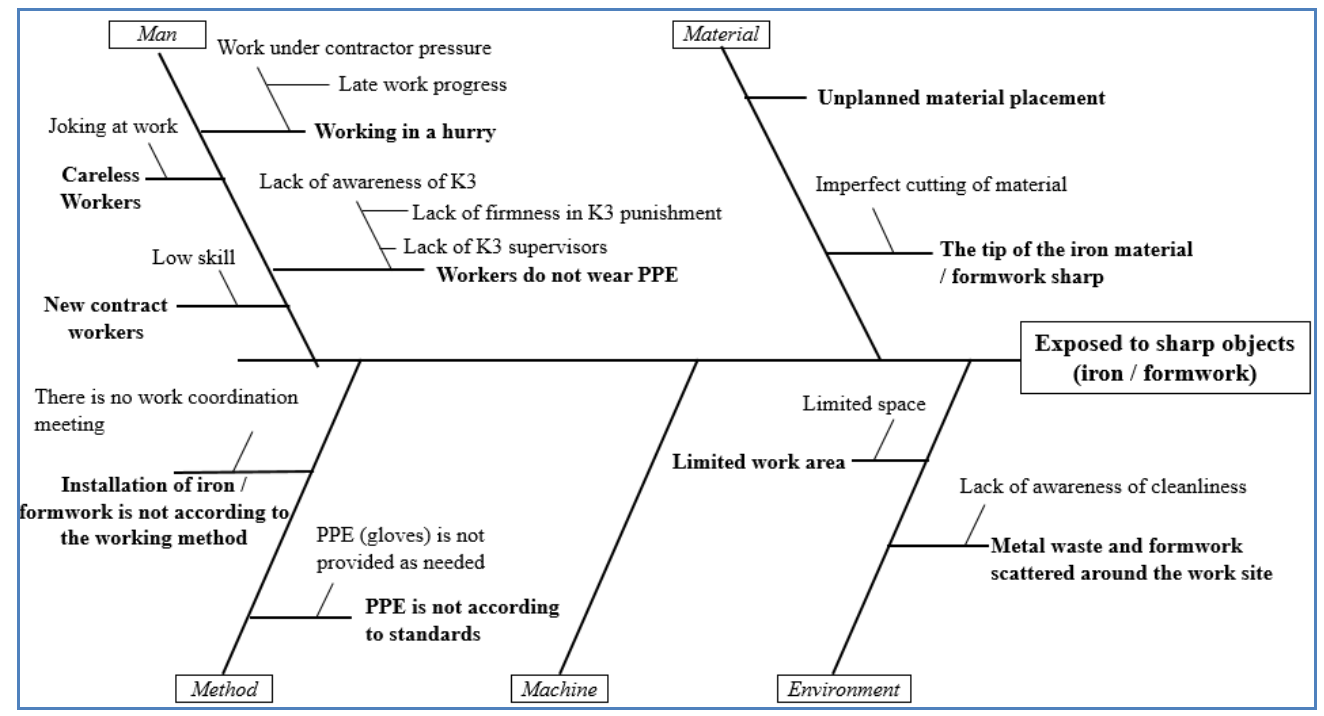

Fig8:-Fishbone diagram of wedged at the time of casting concrete mobilization 


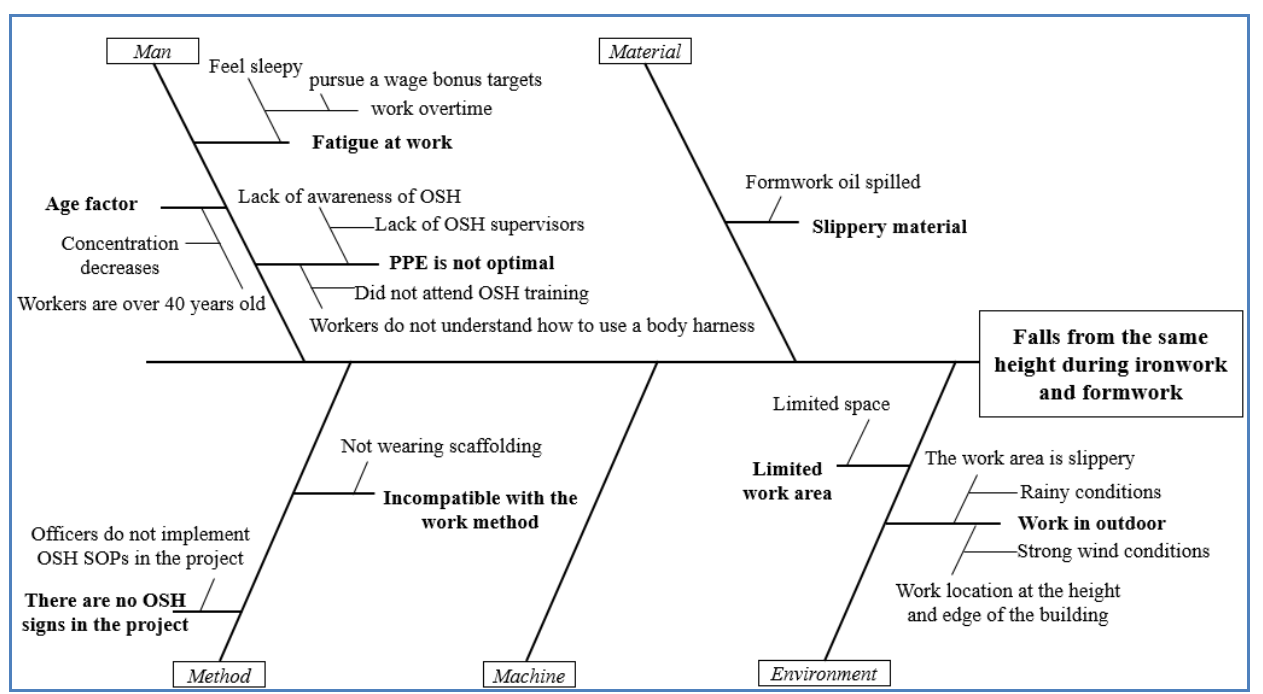

Fig9:-Fishbone diagram of accidents caused by working tools (cutter bar and bar bending)

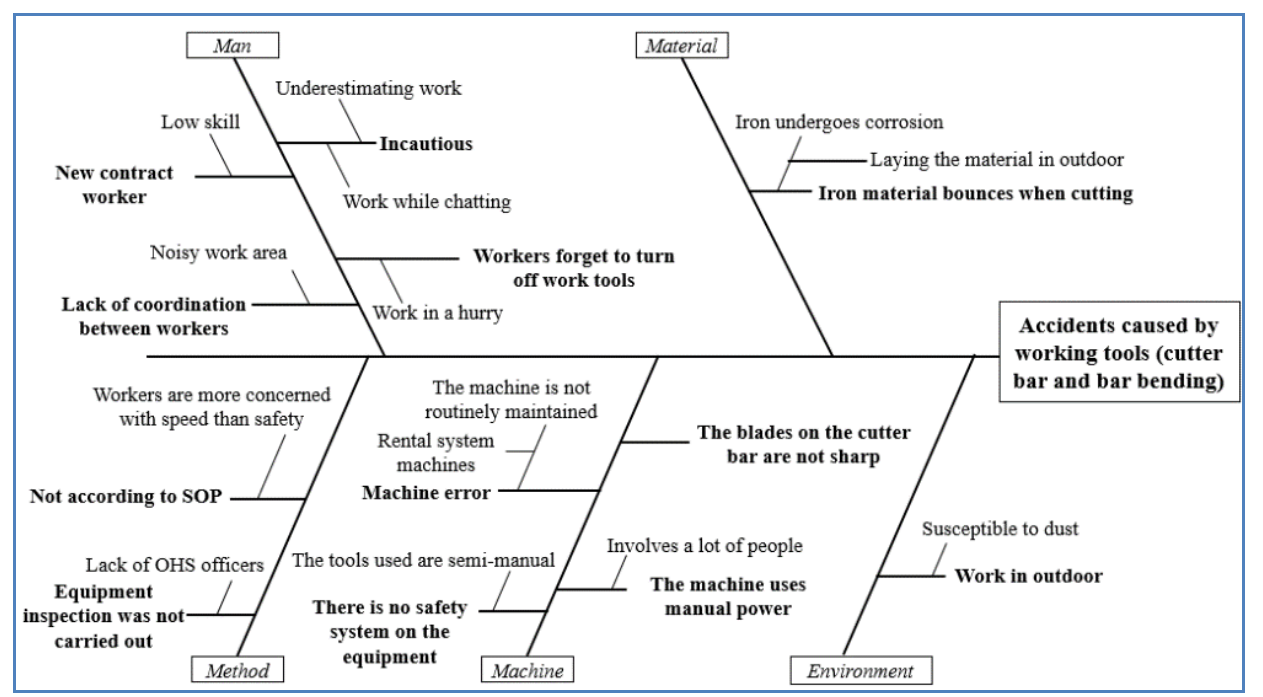

Fig 10:-Fishbone diagram of falls from the same height during ironwork and formwork

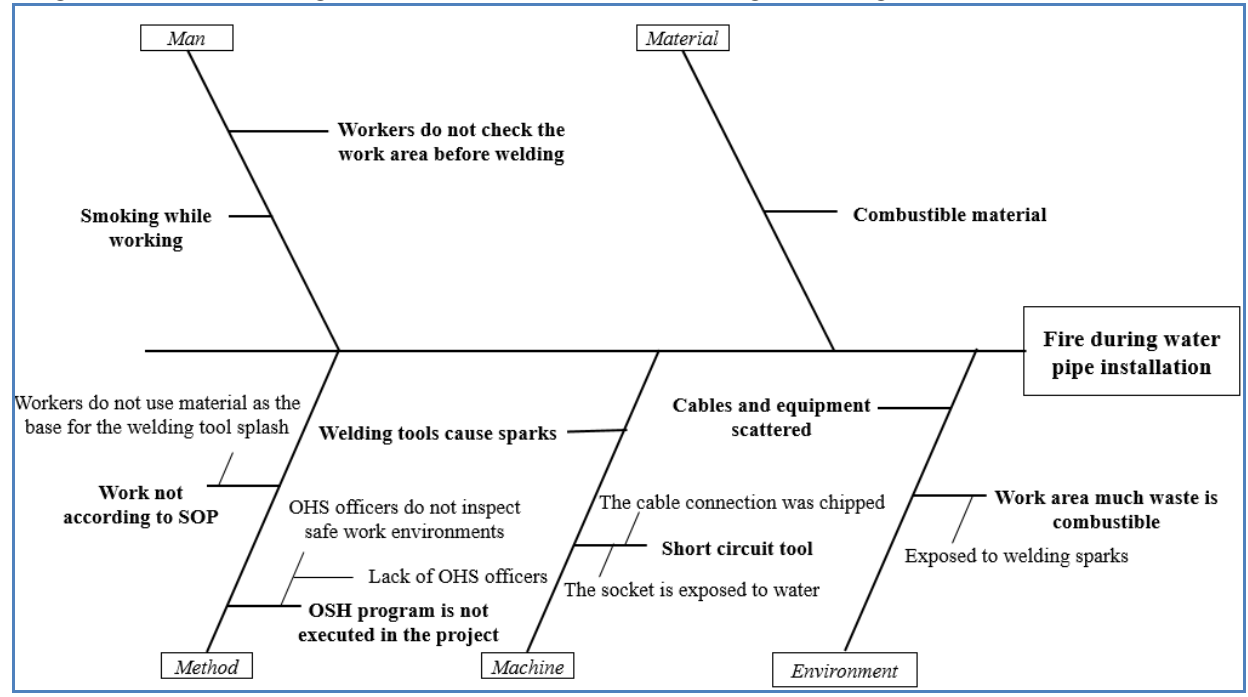

Fig 11:-Fishbone diagram of fire during water pipe installation 


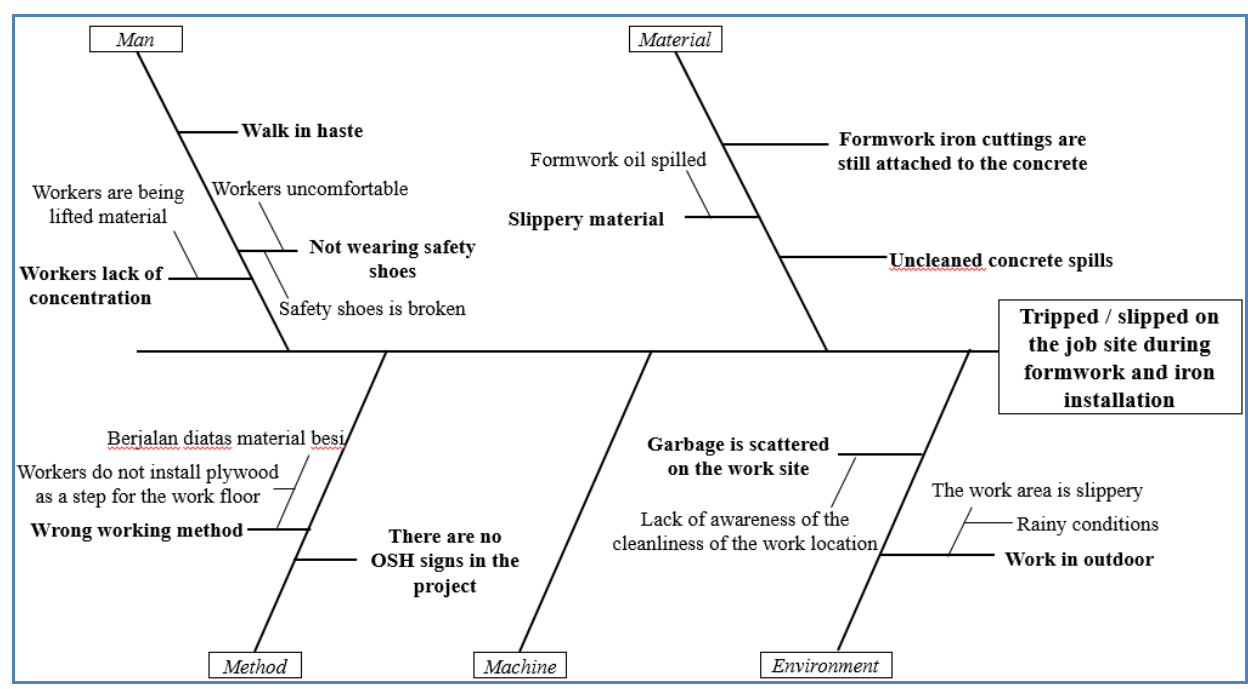

Fig 12:-Fishbone diagram of tripped/ slipped on the job site during formwork and iron instalation

\section{B.Discussion}

There are five factors that influence the high rate of work accidents on the project, namely human factors, method factors, machine factors, material factors and environmental factors. Several types of accidents have almost the same causes.

The human factor is the lack of caution when working, working in a hurry to pursue production targets, fatigue due to overtime work, workers not wearing PPE, age factor so that concentration decreases, low skills of new contract workers and failure of coordination between workers.

The method factor is the use of the wrong work method, the implementation of the operational standard of the OHS worker is not optimal because of the lack of OHS officers.

Machine factor is machine error because it is not routinely maintained, there is no safety system on the machine used, casting with a manual system uses a cast bucket so that the bucket movement is unpredictable, welding equipment causes sparks in locations where there is a lot of waste and short circuiting of work tools due to exposure to water.

Material factors are unplanned material placement, sharp material edges due to imperfect cutting, iron material that bounces off during cutting due to corrosion, reinforcing formwork that is not strong because it is not checked by officers, exposed to clogged concrete pressure because the concrete is too dense, concrete spills that have not been cleaned, iron cuttings are still stuck to the concrete floor, iron material that is slippery due to oil.

Environmental factors are limited work areas so that movement is limited when structural work, iron material and formwork waste are scattered, lack of care for the cleanliness of the work area, work is carried out at night so there is minimal lighting, work is carried out in open areas and the edges of the building, cables and tools that are not tidied up after work.

\section{Man's Factor Improvement}

a. Pre-start briefings must be routinely carried out before workers start work, this is done so that workers know the work targets that must be achieved every day. The contractor's executing role is very important for achieving targets per day, from making daily schedules and achieving targets so that they are in accordance with the master schedule. This effort must be made so that the job target is not late so that workers are not rushed while working.

b. The strategy that must be done to overcome the lack of OHS officers is that the company must change the organizational structure in the project, the occupational health and safety staffs become the coordinator to ensure the OHS program in the project is in accordance with company standards.so that $\mathrm{K} 3$ becomes the responsibility of all parties in the project management.

c. To increase workers' knowledge in using PPE, training should be carried out for the use of personal protective equipment, especially for workers who work at heights and edges of buildings. This training is also conducted in order to increase workers' awareness to always pay attention to safety while working on projects.

d. Officers must remind workers to always focus on working in the field, to make it easier to socialize it requires loudspeakers that are connected from the control room to the speakers in the project area so that all workers can clearly hear the calls of OHS officers when they are on the work location The use of banners can be done as a means of appeal, banners in the form of written slogans or images with attractive designs so that workers are interested in seeing and reading them.

e. Workers with new contracts and less experience working on projects must be recorded and not located in hazardous work areas for example transporting materials and not working at the height / edge of the building. And workers who work at high altitudes must have a special certificate.

f. Regulating overtime hours for workers should be made to prevent workers from taking excessive overtime hours. Workers are not allowed to overtime for two consecutive days, there must be a change of workers every day.This is done so that workers are not tired which can affect safety and productivity at work. Officers in the field must make a report on workers who will be overtime based on suggestions from the sub-contractor and then approved by the project manager so that workers' working hours can be controlled properly.

g. Tower crane riggers must be trained and have a 
certificate. Certificate checking must be done before the rigger works. And also OHS officers must make a rigger training program for workers and employees on the project which is carried out by the National Professional Certification Agency (BNSP).

\section{Method Factor Improvement}

a. The work method must be explained by workers in the field because it contains information about the work steps and also the order of work that must be done by workers to maintain the quality and safety of workers in the field. The role of project officers here is very important because they are responsible for the work done by workers, so project officers must direct and remind workers to always follow the work methods that have been made.

b. The PPE used by workers must comply with company standards. In order for the suitability and completeness of PPE to be properly controlled, companies must screen workers before entering the work area. To maximize the screening process, access to the work area must be closed and only one access for exit and entry is made. every registered worker will get an access card to enter the work area.

c. Supporting elements of work area safety must be considered and adapted to project conditions. although these supporting elements are temporary, they must have good quality and strength. The supporting elements are:

- Railing safety railing must be replaced with appropriate international standards that have been tested strength and also its quality, so it is no longer wearing a metal pipe which are connected with the pipe valve.

- Horizontal \& vertical safety nets should use those that have been fabricated by machines as an investment for subsequent projects, so there is no need for repeated fabrications.

- OHS signs are redesigned using reflective materials and striking colors that are easily visible. And also the use of sign symbols must be socialized to workers so that workers understand the symbol.

- Safety seals for body harness hooks must be placed on each edge of the building and painted a bright color as a marker so workers are easily recognized.

d. Standard operational use of welding equipment at work sites must be carried out, namely by providing a base for collecting sparks. In addition, workers must wear welding gloves and carry a fire extinguisher while working

e. The provision and placement of fire extinguishers should be planned at several points on each floor of the building. OHS officers must provide training to workers on how to use it.

f. Companies need to conduct emergency response simulation training in each project to anticipate when a fire or earthquake occurs. This needs to be done in order to see that the project's security function can run effectively during an emergency and can also train personnel / workers in the project environment so that they do not panic during the emergency response evacuation process.

\section{Material Factor Improvement}

a. Placement of materials on each floor of the building must be planned from the start of the project. Some of the criteria that must be met for material placement are the placement of materials that can be reached by tower cranes, as well as the provision of material transport terminals for each floor and the placement of materials in the work location does not interfere with worker access.

b. Checking the quality of the material must be carried out by quality control officers, one of which is checking the concrete material. Slump check must be done on every mixer truck that enters the project. This slump check serves to determine the level of concrete density on each mixer truck that arrives, because the delivery distance is far from the quality of the concrete to become solid. By doing this check, the quality of the concrete can be treated by adding a concrete thinner liquid so asto minimize clogging of the concrete pump and cast pipes during the casting of the concrete.

c. The placement of iron material must be separated from other materials, the storage location must also have a roof cover to protect the iron from heat and rain, so that the iron material does not experience corrosion. The placement of iron material must also be close to the place of iron production so that it is easier for the mobilization of iron material to the production site.

d. The use of wood material (plywood) for conventional formwork should be replaced with semi-system formwork made of a combination of hollow frames and steel plates, so that the use of oil as formwork lubricant can be eliminated. And also from the resulting quality factor and the duration of use is much better than conventional formwork (wood).

e. The used material waste that is still attached to the floor surface must be cleaned immediately by the worker, the employee who is responsible during structural work must check the work location that has been cast, such as cleaning iron cuttings so that they are immediately removed or cut. and concrete spills are cleaned up immediately before hardening, so that other workers do not trip / slip in the work area.

\section{Machine Factor Improvement}

a. The casting method using a cast bucket is minimized as much as possible when the project conditions have reached a height above ten meters, this method can be replaced with the use of a concrete pump or a concrete pump truck.

b. Equipment inspection must be carried out before the tool is used, one way to check it is by checking the proper operation permit (SILO) on all tools / machines. So that the tool is in good condition when used in the project.

c. The use of a manual bar cutter / bar bending machine must be replaced with an electric powered machine, so that the iron fabrication process does not involve a lot of workers, besides that the level of safety is also higher because it has a safety system on an electric powered machine. so that no iron material is thrown at the time of cutting and it is safe for workers because it does not 
come into direct contact with the blade.

d. Checking the cable connections in the project area, as much as possible there are no cable connections on the tools used so as not to cause a short circuit.

\section{Environment Factor Improvement}

a. Provision of a working floor is adjusted to the number of workers in the area being worked on (structural work), access to the working floor needs to be widened so that it is sufficient for two workers who cross paths. and also access to the work floor must have a marker or signage.

b. Checking waste at work sites must be done every day and increase the provision of trash bins at the project site. To increase awareness of cleanliness, it is necessary to create a program to support this formation, by spending a few hours every week to clean up the project environment which involves all workers and all levels of employees in the project environment that is being implemented.

c. Generally, structural work is carried out in open areas, weather conditions can be an obstacle at work. To prevent accidents due to weather conditions, the installation of scaffolding can be used to prevent workers from climbing the formwork for fixing iron when the work is on the edge of the building. Furthermore, when it rains all activities in the field must be temporarily stopped until the rain stops and also the installation of tarp tents can also be used so that the work area remains dry after the rain. Furthermore, in addition to the use of full body harness PPE, horizontal safety net protection must be installed before carrying out work and the safety net material used must be different from the usual. The use of net nets must be replaced with mine nets so that when an accident occurs, the worker falls from the height of the net that can hold the worker from falling. this is done in order to create a safe work environment.

d. The number and placement of spotlights must adjust to the conditions of the work area so that there are no dark areas at night. This can be controlled by applying an overtime work permit issued by the officer in charge of the work location to the OHS officer, so that checking the work area can be done before the overtime work is carried out.

e. The use of cable hanger poles can be used so that cable laying is not scattered on the work floor. Inspection of the laying of cables and tools / materials that have the potential to cause fires must also be routinely carried out by OHS officers, these checks are checking the protection of the cable connection on the tool or socket, the cable laying is not in a wet area, the paint material and cutting the arc (oxy-cutting) are far from welding tool.

\section{CONCLUSIONS AND SUGGESTIONS}

\section{A. Conclusions}

Based on analysis description results therefore it could be drawn as concluded that:

1) After calculating, the results of the highest RPN value were exposed to sharp objects when installing iron and formwork at 60 , fall from a height when concrete casting by 30 , pinched during material mobilization of the concrete material by 30 , accidents caused by working tools during iron and formwork amounted to 18, fall from the same height while working iron construction by 18 , fire caused by welding at the time of installing the water pipe by 16, tripping / slipping at the work location during the installation of iron and formwork by 15 . Based on the analysis, work accidents often occur during structural work.

2)Factors that influence the high rate of work accidents on the project, namely: Human factors are the lack of caution while working, working hastily to pursue production targets, fatigue due to overtime work, workers not wearing PPE, age factor so that concentration decreases, low worker skills and failure of coordination between workers.Factor method is the use of the wrong work methods, implementation of operational standards for OHS work is not maximized due to lack of OHS officers. The machine factor is that there is no safety system on the machine used, casting with a manual system uses a cast bucket so that the bucket movement is unpredictable, short circuiting on the tool because it is exposed to water.Material factors are unplanned material placement, sharp material edges due to imperfect cutting, iron material bouncing during cutting due to corrosion, reinforcing formwork that is not strong because it is not checked by officers, exposed to clogged concrete pressure because the concrete is too dense, concrete spills that have not been cleaned, iron cuttings are still stuck to the concrete floor. Environmental factors are limited work areas so that movement is limited when structural work, iron material and formwork waste are scattered, lack of care for the cleanliness of the work area, work is carried out at night so there is minimal lighting, work is carried out in open areas and the edges of the building, cables and tools that are not tidied up after work.

3) The improvements made were the method factor, namely the improvement in the method of implementing project safety support elements, making a one gate system as an access in and out of workers to facilitate screening of PPE workers and provision of emergency response training. Environmental factors, namely updating of work operational standards by checking the conditions of the work environment before work is carried out by OHS officers and site operational managers (SOM). Material factors, namely providing protection for material storage, checking the quality of the main raw materials carried out by quality control officers and cleaning used materials that are still attached after casting. The machine factor is checking the operational permit for each tool before the equipment arrives, doing preventive maintenance on every tool used in the project and updating the tools with a safer work system. Man factors are changes in project operational management structure, application of punishment for workers who violate K3 rules, and implementation of workforce training accompanied by the National Professional Certification Agency (BNSP).

\section{B.Suggestions}

1) Based on work accident data for the last three years, 
accidents due to being hit by sharp objects during the installation of iron and formwork had the highest RPN value. This is because the workers are not disciplined in using PPE according to company standards, so contractors must work together to pay attention to the completeness and application of PPE to workers.

2) Based on the severity of work accidents, accidents due to falling from a height require special attention. This accident occurs because most of the workers who work at height do not have a work from height certificate, so each project must ensure that workers who work at this height must attend training and have this certification.

3) In the actual conditions found, it was found that the company's standardization of work operational standard factors and HSE factors in each project was still different. So the company should do an evaluation related to company standardization. With the hope that the results of the analysis obtained from this study can be a reference for improvement.

\section{REFERENCES}

[1] Apriyan, J., Setiawan, H., \& Ervianto, W. . (2017). Analisis Risiko Kecelakaan Kerja Pada Proyek Bangunan Gedung Dengan Metode fmea 1. Jurnal Muara, 1(1), 116.

[2] Benny Hidayat, \& Anggraini, R. F. \& N. (2016). Kecelakaan Kerja Proyek Konstruksi Di Indonesia Tahun 2005-2015, (October).

[3] Coccia, M. (2017). The Fishbone diagram to identify, systematize and analyze the sources of general purpose technologies. Journal of Social and Administrative Sciences, 4(4). https://doi.org/10.1453/jsas.v4i4.1518

[4] Dauly, F. A. (2010). Faktor-faktor Yang Berhubungan Dengan Kecelakaan Kerja Pada Buruh Konstruksi Di Pt. PP (Persero) Proyek Tiffani Apartemen Kemang Jakarta Selatan.

[5] Fitriyaningrum. (2018). ANALISA PENENTUAN NILAI PRIORITAS KECELAKAAN KERJA DENGAN METODE FAILURE MODE AND EFFECT ANALYSIS DI PT. ASTOM INDONESIA.

[6] Kangavari, M., Salimi, S., Nourian, R., Omidi, L., \& Askarian, A. (2015). application of failure mode and effect analysis ( FMEA ) to assess risks in petrochemical industry in Iran An application of failure mode and effect analysis ( FMEA ) to assess risks in petrochemical industry in Iran. Iranian Journal of Health, Safety \& Environment, 2(2), 257-263.

[7] Levi, A. (2017). Usulan Perbaikan Keselamatan Kerja Menggunakan Metode Job Safety Analysis (JSA) Dan Failure Mode And Effect Analysis (FMEA). Spektrum Industri, 15(2), 121 - 255.

[8] Sebastianus, B. H. (2015). Manajemen keselamatan dan kesehatan kerja sebagai peranan pencegahan kecelakaan kerja di bidang konstruksi. Seminar Nasional Teknik Sipil V Tahun 2015 - UMS, 5, 301-308.

[9] Suryani, F. (2018). PENERAPAN METODE DIAGRAM SEBAB AKIBAT ( FISH BONE DIAGRAM ) DAN FMEA ( FAILURE MODE AND EFFECT ) DALAM MENGANALISA RESIKO KECELAKAN KERJA DI PT . PERTAMINA, 3(2).

Rosalendro Eddy Nugroho is currently a fulltime senior lecturer in Master Program in Post-Graduate Management from Universitas Mercu Buana Jakarta. He holds a Bachelor of Science degree in Chemichal Engineering from Gadjah Mada University, Master of Management from Universitas Satyagama Jakarta, and $\mathrm{PhD}$ in Management from Bogor Agriculture University. He has taught courses in operation management, supply chain management, enterprise resource planning, Quality Assurance Management, Heath Safety \& Enviroment Mangement, Investation \&Financial Management and managerial economic.

Angga Sunbara is Students of the Postgraduate Management Masters Program at the University of Mercu Buana Jakarta. He worked as an officer quatity surveyor at PT PP (Persero) Tbk Indonesia, Building Engineering Division. 